\title{
Frequency distribution of pollutant concentrations over Indian megacities impacted by the COVID-19 lockdown
}

\author{
Arnab Mondal ${ }^{1,2}\left(\mathbb{0} \cdot\right.$ Sudhir Kumar Sharma ${ }^{1,2} \cdot$ Tuhin Kumar Mandal $^{1,2} \cdot$ Imran Girach $^{3} \cdot$ Narendra Ojha $^{4}$
}

Received: 27 April 2021 / Accepted: 30 September 2021 / Published online: 21 October 2021

(c) The Author(s), under exclusive licence to Springer-Verlag GmbH Germany, part of Springer Nature 2021

\begin{abstract}
The megacities experience poor air quality frequently due to stronger anthropogenic emissions. India had one of the longest lockdowns in 2020 to curb the spread of COVID-19, leading to reductions in the emissions from anthropogenic activities. In this article, the frequency distributions of different pollutants have been analysed over two densely populated megacities: Delhi $\left(28.70^{\circ} \mathrm{N} ; 77.10^{\circ} \mathrm{E}\right)$ and Kolkata $\left(22.57^{\circ} \mathrm{N} ; 88.36^{\circ} \mathrm{E}\right)$. In Delhi, the percentage of days with $\mathrm{PM}_{2.5}$ levels exceeding the National Ambient Air Quality Standards (NAAQS) between 25 March and 17 June dropped from 98\% in 2019 to $61 \%$ in 2020. The lockdown phase 1 brought down the $\mathrm{PM}_{10}$ (particulate matter having an aerodynamic diameter $\leq 10 \mu \mathrm{m}$ ) levels below the daily NAAQS limit over Delhi and Kolkata. However, $\mathrm{PM}_{10}$ exceeded the limit of $100 \mu \mathrm{gm}^{-3}$ during phases $2-5$ of lockdown over Delhi due to lower temperature, weaker winds, increased relative humidity and commencement of limited traffic movement. The $\mathrm{PM}_{2.5}$ levels exhibit a regressive trend in the highest range from the year 2019 to 2020 in Delhi. The daily mean value for $\mathrm{PM}_{2.5}$ concentrations dropped from $85-90 \mu \mathrm{gm}^{-3}$ to $40-45 \mu \mathrm{gm}^{-3}$ bin, whereas the $\mathrm{PM}_{10}$ levels

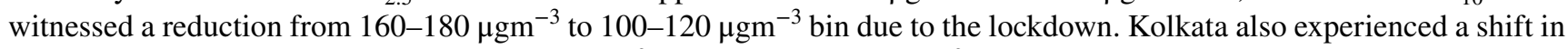
the peak of $\mathrm{PM}_{10}$ distribution from $80-100 \mu \mathrm{gm}^{-3}$ in 2019 to $20-40 \mu \mathrm{gm}^{-3}$ during the lockdown. The $\mathrm{PM}_{2.5}$ levels in peak frequency distribution were recorded in the $35-40 \mathrm{\mu gm}^{-3}$ bin in 2019 which dropped to $15-20 \mu \mathrm{gm}^{-3}$ in 2020 . In line with particulate matter, other primary gaseous pollutants $\left(\mathrm{NO}_{\mathrm{x}}, \mathrm{CO}, \mathrm{SO}_{2}, \mathrm{NH}_{3}\right)$ also showed decline. However, changes in $\mathrm{O}_{3}$ showed mixed trends with enhancements in some of the phases and reductions in other phases. In contrast to daily mean $\mathrm{O}_{3}, 8$-h maximum $\mathrm{O}_{3}$ showed a reduction over Delhi during lockdown phases except for phase 3. Interestingly, the time of daily maximum was observed to be delayed by $\sim 2 \mathrm{~h}$ over Delhi (from 1300 to $1500 \mathrm{~h}$ ) and $\sim 1 \mathrm{~h}$ over Kolkata (from 1300 to $1400 \mathrm{~h}$ ) almost coinciding with the time of maximum temperature, highlighting the role of meteorology versus precursors. Emission reductions weakened the chemical sink of $\mathrm{O}_{3}$ leading to enhancement $(120 \% ; 11 \mathrm{ppbv})$ in night-time $\mathrm{O}_{3}$ over Delhi during phases $1-3$.
\end{abstract}

Keywords Frequency distribution · COVID-19 $\cdot$ Lockdown $\cdot$ NAAQS $\cdot$ Anthropogenic emissions $\cdot$ Megacities

\section{Introduction}

Responsible Editor: Lotfi Aleya

Arnab Mondal

arnabmondal66@gmail.com

1 CSIR-National Physical Laboratory, Dr. K. S. Krishnan Marg, New Delhi 110 012, India

2 Academy of Scientific and Innovative Research (AcSIR), Ghaziabad 201 002, India

3 Space Physics Laboratory, Vikram Sarabhai Space Centre, Thiruvananthapuram 695 022, India

4 Physical Research Laboratory, Navrangpura, Ahmedabad 380 009, India
The air pollution levels are often observed to be in exceedance of the National Ambient Air Quality Standards (NAAQS) limits (Table ST1) over the megacities of India (Gurjar et al. 2016; Sen et al. 2017; Singh et al. 2021). Considering the adverse effects of air pollution on health and agricultural productivity in the region, poor air quality is of profound scientific and policy interest (Chowdhury et al. 2019; Ghude et al. 2016; Lelieveld et al. 2015; Sharma et al. 2019). Besides atmospheric dynamics and meteorology, the air pollution levels over Indian cities are also enhanced by strong local anthropogenic emissions and photochemistry (Ansari et al. 2016; Dhaka et al. 2020; Kumar et al. 2015; 
Ojha et al. 2012, 2020). Additionally, biomass-burning emissions, natural emissions and chemistry play important roles in photochemical ozone buildup (Kumar et al. 2016, 2018). Several studies have highlighted the complex interplay between meteorological conditions and aforementioned diverse emissions in affecting air quality over the Indian region (Dhaka et al. 2020; Ojha et al. 2020; Singh et al. 2020). However, it remains unclear how the reductions in regional emissions could help in improving the air quality in the Indian megacities. Studies based on chemical transport modelling have provided first-hand information; however, considerable biases are seen when model simulations are compared with in situ measurements over India (Chutia et al. 2019; Ojha et al. 2012, 2020; Sharma et al. 2017).

Stringent lockdowns to contain the spread of COVID19 resulted in considerable reductions in the anthropogenic emissions allowing researchers to assess the impacts of local and regional emissions on the air quality over different environments. In this regard, numerous studies have recently evaluated the effects of lockdown on the air pollution by analysing satellite-based and ground-based observations globally as well as in the Indian region (Dhaka et al. 2020; Le et al. 2020; Singh \& Chauhan 2020; Singh et al. 2020). A few studies also reported the declining trend in the air quality index (AQI) (Nigam et al. 2021; Srivastava et al. 2020) and reduction in aerosol optical depth over the IndoGangetic basin (Srivastava et al. 2021). These studies, along with several other efforts, established general reductions in the concentrations of primary air pollutants; however, enhancements in surface $\mathrm{O}_{3}$ were observed in some urban and rural environments during the lockdown.

India experienced one of the most comprehensive lockdowns of the world which led to unprecedented reductions in the emissions from the traffic, industries, as well as from other sectors (Dhaka et al. 2020; Singh et al. 2020). Table 1 lists the different lockdown phases in India with the duration, restriction and relaxation guidelines during the different phases (Mondal et al. 2021). The phase 5 lockdown was lifted in a controlled manner unlike the earlier phases (phases 1-4). Analysis of satellite-based observations revealed that mean $\mathrm{NO}_{2}$ levels over India were lowered by $17-18 \%$ as compared to the pre-lockdown period and 5-year average (Pathakoti et al. 2020). Analysis of ground-based measurements across the Indian region revealed sharp reductions by $\sim 40-60 \%$ in $\mathrm{PM}_{2.5}$ and $\mathrm{PM}_{10} ; \sim 30-70 \%$ in $\mathrm{NO}_{2}$ and $\sim 20-40 \%$ in CO (Singh et al. 2020). Large reductions in the $\mathrm{PM}_{2.5}$ levels (by 40-70\%) during the first week of the lockdown were also reported from the Delhi region; however, some haze was observed due to interplay of baseline pollution and meteorological conditions (Dhaka et al. 2020). Mixed changes were observed in cases of $\mathrm{O}_{3}$ and $\mathrm{SO}_{2}$ over Indian environments (Dhaka et al. 2020; Girach et al. 2021; Singh et al. 2020; Soni et al. 2021). Nevertheless, it remains unclear how the frequency distributions of air pollutants were impacted by emission reductions during lockdown. The pollutant concentrations typically have skewed distributions, and the changes only in mean and median are insufficient to assess the change in air quality; therefore, the analyses of frequency distributions are very useful (Miles et al. 1991; Sarangi et al. 2014). Additionally, such an analysis would provide a quantitative picture of the likely range of concentrations in a possible mitigation scenario, such as that during the COVID-19 lockdown. A particularly important part of the distribution is the higher side of the pollution concentrations which are extremely sensitive to the emissions and stagnant meteorological conditions. A frequency distribution can also be used for the prediction of pollutant levels using Lognormal, Weibull and type V Pearson distributions. Lu (2003) concluded in a study that the lognormal distribution can closely predict the particulate matter concentrations as compared to type V Pearson and Weibull distributions which over-estimated and under-estimated the actual values respectively. Further, concentrations of air pollutants and the frequency distributions are important factors in assessments

Table 1 Lockdown phases, duration and imposed restrictions/relaxations over India

\begin{tabular}{|c|c|c|c|c|}
\hline Lockdown phases & From & To & Duration & Restrictions and relaxations \\
\hline Phase 1 & $25^{\text {th }}$ March 2020 & $14^{\text {th }}$ April 2020 & 21 days & $\begin{array}{l}\text { Complete lockdown with relaxations to healthcare workers and daily } \\
\text { need item suppliers only }\end{array}$ \\
\hline Phase 2 & $15^{\text {th }}$ April 2020 & $3^{\text {rd }}$ May 2020 & 19 days & $\begin{array}{l}\text { Complete lockdown and relaxations limited to 'green zones' (where } \\
\text { there were no reported cases of CoVID-19) only }\end{array}$ \\
\hline Phase 3 & $4^{\text {th }}$ May 2020 & $17^{\text {th }}$ May 2020 & 14 days & $\begin{array}{l}\text { Complete lockdown and relaxations to green zones only. The transport } \\
\text { buses were allowed to operate with } 50 \% \text { capacity in green zones only }\end{array}$ \\
\hline Phase 4 & $18^{\text {th }}$ May 2020 & $31^{\text {st }}$ May 2020 & 14 days & $\begin{array}{l}\text { Lockdown for red zones only (where there were active CoVID-19 } \\
\text { cases) and relaxations given to green zones only. Indian railways and } \\
\text { airlines resumed operations with low capacity }\end{array}$ \\
\hline Phase 5 (a.k.a. Unlock 1) & $1^{\text {st }}$ June 2020 & $30^{\text {th }}$ June 2020 & 30 days & $\begin{array}{l}\text { Lockdown restrictions limited to 'containment zones' (with high } \\
\text { number of active CoVID-19 cases). For all other zones, restrictions } \\
\text { removed except large public gathering and opening of theatres, gyms, } \\
\text { hotels, swimming pools, parks, bars, auditorium etc }\end{array}$ \\
\hline
\end{tabular}


of human health risks (Saltzman 1997). This is of paramount significance for potential policy-making for mitigating pollution episodes over the Indian megacities. In this direction, the present study is aimed to analyse the frequency distributions of key air pollutants over two Indian megacities.

\section{Data and methodology}

This study analyses the ground-based observations of the ambient air quality over a network of monitoring stations in two megacities of India: Delhi $\left(28.6^{\circ} \mathrm{N} ; 77.2^{\circ} \mathrm{E}, 200-250 \mathrm{~m}\right.$ amsl) and Kolkata $\left(22.6^{\circ} \mathrm{N} ; 88.4^{\circ} \mathrm{E}, \sim 9 \mathrm{~m}\right.$ amsl). Delhithe national capital of India and Kolkata-the cultural capital of India have about 16 and 14 million population, respectively (Census of India, 2011; https://censusindia.gov. in/2011). These megacities experience poor air quality frequently exceeding the NAAQS limits of various pollutants (Firdaus and Ahmad 2011; Gupta et al. 2007; Molina and Molina 2004). The observations were taken from 38 stations for Delhi and 2 stations for Kolkata (as described in the supplementary Table ST2) operated and maintained by Central Pollution Control Board (CPCB) along with Delhi Pollution Control Committee (DPCC), West Bengal Pollution Control Board (WBPCB) and India Meteorological Department (IMD). Two years (2019 and 2020) of observations on daily basis were analysed to estimate the impact of lockdown on the levels and frequency distribution of air pollutants. The stations which had observations of all the species- $\mathrm{PM}_{2.5}$, $\mathrm{PM}_{10}, \mathrm{NO}_{2}, \mathrm{SO}_{2}, \mathrm{O}_{3}, \mathrm{CO}$ and $\mathrm{NH}_{3}$ between 25 March and 17 June for both 2019 and 2020 (lockdown period) were considered for the analyses. There are 7 monitoring stations installed throughout Kolkata out of which just 2 stations recorded all the parameters $\left(\mathrm{PM}_{2.5}, \mathrm{PM}_{10}, \mathrm{NO}_{2}, \mathrm{SO}_{2}, \mathrm{O}_{3}, \mathrm{CO}\right.$ and $\mathrm{NH}_{3}$ ) for both the years 2019 and 2020. We suggest that more denser monitoring network for air quality parameter measurements are required, especially in Kolkata, which can provide further insights in the air quality data. Daily mean of particulate matter $\left(\mathrm{PM}_{2.5}\right.$ and $\left.\mathrm{PM}_{10}\right)$ and pollutant gas $\left(\mathrm{NO}_{2}, \mathrm{SO}_{2}\right.$ and $\left.\mathrm{NH}_{3}\right)$ concentrations were used in the analyses. In addition to daily average, 1 -h and 8 -h averages are also used in cases of $\mathrm{O} 3$ and $\mathrm{CO}$ since considering the NAAQS limits. Daily data were screened for values beyond 3-sigma standard deviations for removal of spikes/abnormal values prior the analyses.

\section{Results and discussions}

The effects of lockdown on air quality are investigated by comparing the ground-based observations of $\mathrm{PM}_{2.5}, \mathrm{PM}_{10}$, $\mathrm{O}_{3}, \mathrm{CO}, \mathrm{NO}_{2}, \mathrm{SO}_{2}$ and $\mathrm{NH}_{3}$ over the Indian megacities during the lockdown and the same period of the year 2019 . Besides the changes in mean concentrations given in the Table 2, here the emphasis is on the frequency distributions of pollution concentrations to provide a reference for potential future policies to improve regional air quality. The frequency distribution of the pollutant's concentrations provides the statistical characteristics of the air quality variations (Seinfeld and Pandis 1998). In addition to unravel the spread in the pollution levels and most frequent ranges of variation, the skewness indicates on the source characteristics (Seinfeld and Pandis 1998). The frequency distributions of the pollution concentrations exhibit large variations and also depend on meteorological conditions, besides emissions (Lu and Fang 2002).

\section{$\mathrm{PM}_{2.5}$ and $\mathrm{PM}_{10}$}

The NAAQS safe limit for $\mathrm{PM}_{25}$ annual and daily average concentrations is $40 \mu \mathrm{gm}^{-3}$ and $60 \mathrm{\mu gm}^{-3}$ respectively. The average $\mathrm{PM}_{2.5}$ and $\mathrm{PM}_{10}$ concentrations over Delhi were found to be $82.2 \pm 27.7 \mu \mathrm{gm}^{-3}$ and $236.5 \pm 75.2$ $\mathrm{\mu gm}^{-3}$ respectively during the year 2019 (25th March-30th

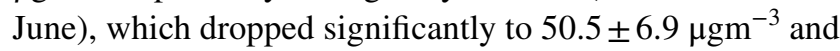
$120.05 \pm 26.2 \mu \mathrm{gm}^{-3}$ due to lockdown in 2020 (Table 2). The reduction in $\mathrm{PM}_{2.5}$ concentrations by $11.6-53.8 \mu \mathrm{gm}^{-3}$ during the $1^{\text {st }}$ phase of lockdown brought it below NAAQS limit over Delhi (Figure S2). The strong shift in the frequency distribution towards the lower range of the $\mathrm{PM}_{2.5}$ concentrations is clearly visible (Fig. 1b). In Delhi, $77 \%$ of the total days experienced $\mathrm{PM}_{2.5}$ levels above the NAAQS during 25 March to 17 June 2019 which dropped to $21 \%$ in the year 2020 due to the lockdown. However, following relaxations towards the phases $4-5$ of lockdown $\mathrm{PM}_{2.5}$ again showed enhancements (Fig. 1a). Kolkata also experienced drop of

Table 2 Mean concentration levels of pollutants over the Indian megacities during lockdown period (25 March-17 June) of 2020 and same period in the preceding year. The mean values are calculated from daily averages of pollutants concentration

\begin{tabular}{lllllllll}
\hline Megacity & Year & $\mathrm{PM}_{2.5}\left(\mu \mathrm{gm}^{-3}\right)$ & $\mathrm{PM}_{10}\left(\mu \mathrm{gm}^{-3}\right)$ & $\mathrm{NO}_{2}\left(\mu \mathrm{gm}^{-3}\right)$ & $\mathrm{O}_{3}\left(\mu \mathrm{gm}^{-3}\right)$ & $\mathrm{SO}_{2}\left(\mu \mathrm{gm}^{-3}\right)$ & $\mathrm{CO}_{\left(\mathrm{mgm}^{-3}\right)} \mathrm{NH}_{3}\left(\mu \mathrm{gm}^{-3}\right)$ \\
\hline Delhi & 2019 & $82.22 \pm 27.70$ & $236.57 \pm 75.26$ & $48.15 \pm 10.98$ & $48.54 \pm 8.30$ & $19.28 \pm 4.76$ & $1.33 \pm 0.28$ & $33.79 \pm 5.74$ \\
& 2020 & $50.57 \pm 6.97$ & $120.05 \pm 26.25$ & $23.70 \pm 4.56$ & $49.58 \pm 9.66$ & $14.71 \pm 1.46$ & $0.85 \pm 0.17$ & $30.23 \pm 2.87$ \\
\multirow{3}{*}{ Kolkata } & 2019 & $42.29 \pm 14.77$ & $88.38 \pm 33.18$ & $24.72 \pm 15.34$ & $29.23 \pm 9.09$ & $4.27 \pm 3.77$ & $0.503 \pm 0.09$ & $13.32 \pm 8.86$ \\
& 2020 & $19.87 \pm 10.06$ & $41.76 \pm 13.27$ & $9.37 \pm 2.34$ & $44.07 \pm 13.07$ & $6.96 \pm 1.58$ & $0.505 \pm 0.18$ & $23.57 \pm 4.92$ \\
\hline
\end{tabular}




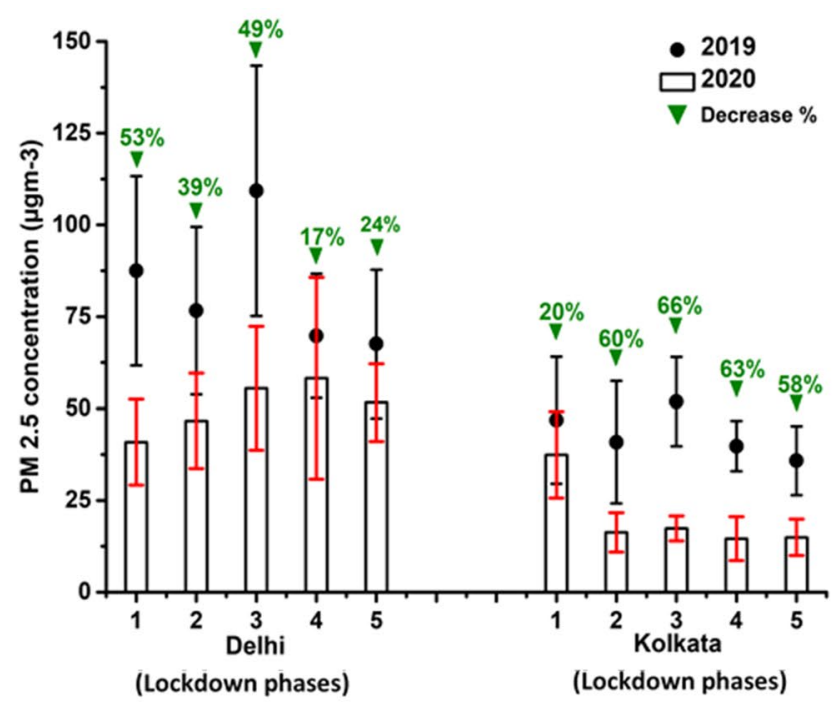

(a)

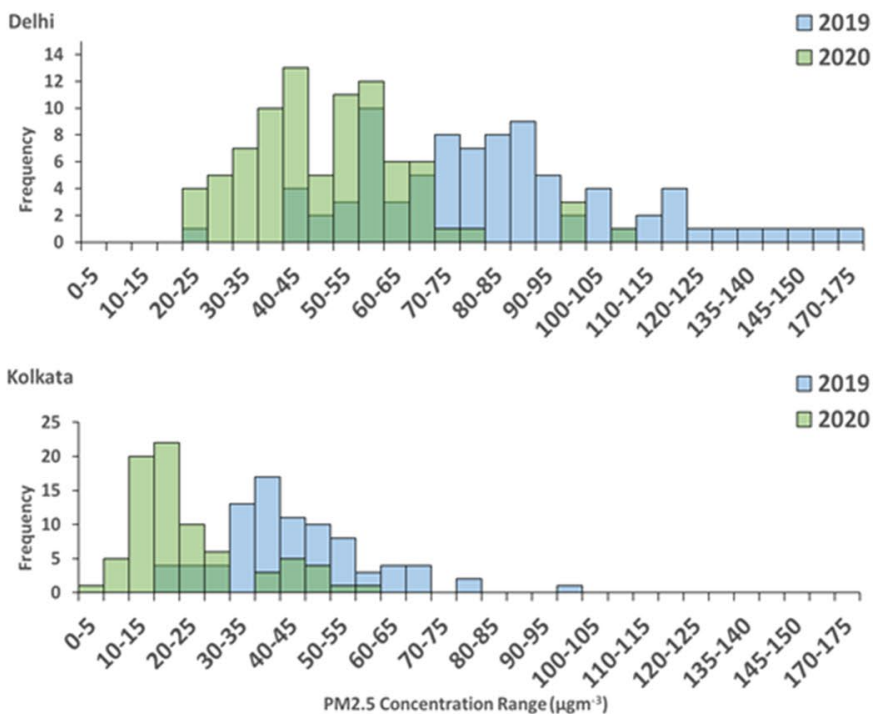

(b)

Fig. 1 (a) Change in daily $\mathrm{PM}_{2.5}$ concentrations; (b) frequency distribution of $\mathrm{PM}_{2.5}$ concentrations during the lockdown phases of 2020 and the same period of 2019

about $13 \%$ of the days with higher levels of ambient $\mathrm{PM}_{2.5}$ during 2020 than the preceding year. The mean concentration levels of $\mathrm{PM}_{2.5}$ in Kolkata during 2019 dropped from $42.2 \pm 14.7{\mu \mathrm{gm}^{-3}}^{-3}$ to $19.8 \pm 10.06 \mu \mathrm{gm}^{-3}$, while the $\mathrm{PM}_{10}$ level dropped from $88.3 \pm 33.1 \mu \mathrm{gm}^{-3}$ to $41.7 \pm 13.2 \mu \mathrm{gm}^{-3}$ due to the lockdown.

$\mathrm{PM}_{10}$ levels over Delhi were mostly above the daily NAAQS limit $\left(100 \mathrm{\mu gm}^{-3}\right)$ during 2019 (Figure S1). The reduction of $\mathrm{PM}_{10}$ to $120.1 \pm 26.3 \mu \mathrm{gm}^{-3}$ concerning 2019 levels $\left(236.2 \pm 39.8 \mathrm{\mu gm}^{-3}\right)$ reveals strong decline by about $50 \%$. The lockdown phase 1 brought down the $\mathrm{PM}_{10}$ levels below the daily NAAQS limit over Delhi. However, $\mathrm{PM}_{10}$ increased again exceeding $100 \mu \mathrm{gm}^{-3}$ during the phases $2-5$ of lockdown over Delhi (Fig. 2a). The increase in particulate matter loading during the lockdown phase 2 in Delhi could have resulted due to sudden change in weather plus

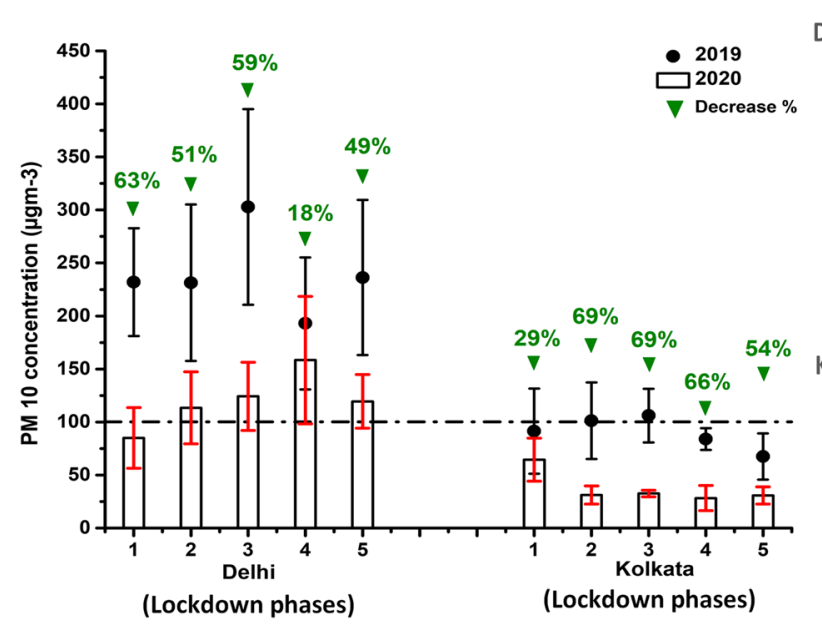

(a)
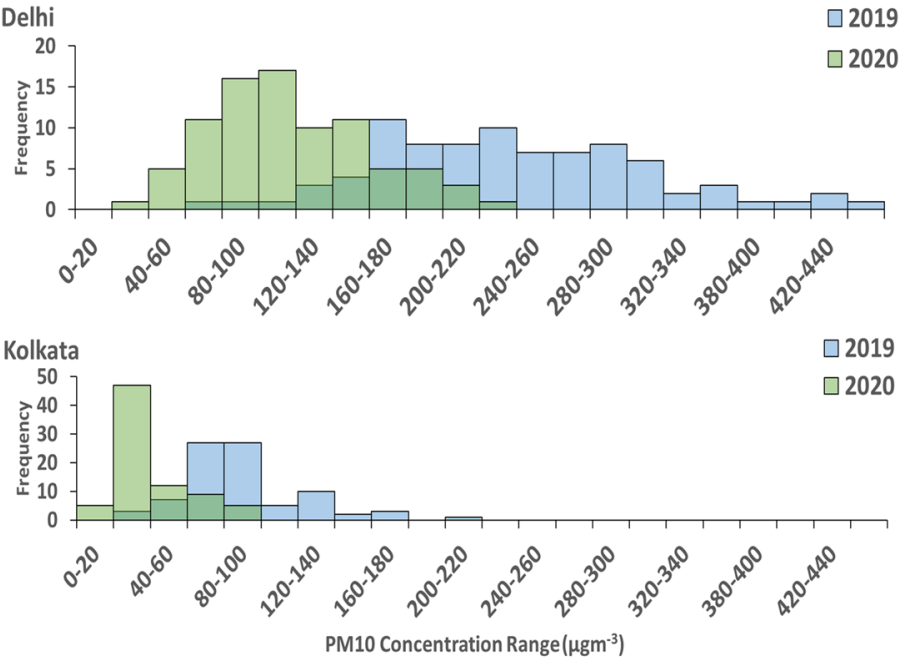

(b)

Fig. 2 (a) Change in daily $\mathrm{PM}_{10}$ concentrations; (b) frequency distribution of $\mathrm{PM}_{10}$ concentrations during lockdown phases of 2020 and the same period of 2019 
gusty winds $\left(18^{\text {th }}\right.$ April 2020$)$ in the northern India region. Relaxation allowing some market places and the transport from phase 3 (from $4^{\text {th }}$ May, 2020) onwards in a controlled manner also contributed to the observed recovery in the pollution loading. The reductions were estimated in the range of 33.7-177.1 ${\mu \mathrm{gm}^{-3}}^{-3}(18-59 \%)$ during other phases. The

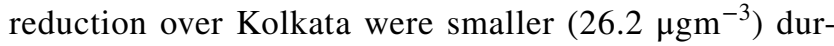
ing phase 1 , whereas, larger reductions by $36.7-67 \mu \mathrm{gm}^{-3}$ (52-66\%) were observed during phases 2-5. In contrast with Delhi, lower $\mathrm{PM}_{10}$ concentrations during phase 4 over Kolkata were due to state-level restrictions on vehicular movements. Delhi and Kolkata recorded about $98 \%$ and $24.7 \%$ of the total days (lockdown period) with pollution exceeding $100 \mathrm{\mu gm}^{-3}$ during 2019 which dropped to $61 \%$ and $0 \%$, respectively due to lockdown in 2020 . The frequency distribution for Delhi (Fig. 2b) shows that the number of days with pollution levels above the NAAQS safe limit are less and PM10 peak shifted to lower range (20-240 ${\mu \mathrm{gm}^{-3}}^{-3}$ during entire lockdown period as compared to the peak variations over $20-460 \mu \mathrm{gm}^{-3}$ during 2019. $\mathrm{PM}_{10}$ variations over Kolkata were also distributed over a broader range 0-220

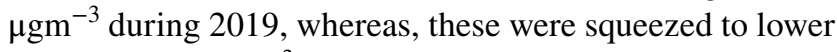
range $\left(0-100 \mu \mathrm{gm}^{-3}\right)$ during the lockdown period.

\section{$\mathrm{O}_{3}, \mathrm{CO}, \mathrm{NOx}$}

Figure $3 \mathrm{a}$ shows that the daily mean $\mathrm{O}_{3}$ levels were decreased by $12 \%$ and $15 \%$ during the phases 1 and 5 respectively as compared to the preceding year, whereas an increase by $15.2 \mathrm{\mu gm}^{-3}(33 \%)$ was seen at surface $\mathrm{O}_{3}$ levels during the phase 3 . Few studies have reported a decrease in $\mathrm{O}_{3}$ over Delhi during the initial stage (phase 1) of lockdown earlier (Sathe et al. 2021; Saxena and Raj 2021). However, Kolkata witnessed a significant rise in daily $\mathrm{O}_{3}$ concentra-

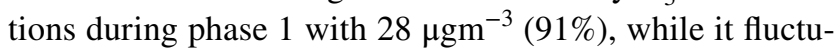
ated between 3.8 and $11.3{\mu \mathrm{gm}^{-3}}^{-3}(11-42 \%)$ during phases $2-5$. The 8-h maximum $\mathrm{O}_{3}$ remained just below the NAAQS limit $\left(100 \mu \mathrm{gm}^{-3}\right)$ during 2019 over Delhi (Figure S3). The highest 8-h $\mathrm{O}_{3}$ levels were lower during the lockdown as compared to 2019. As shown in Fig. 3b, O3 shows reduction

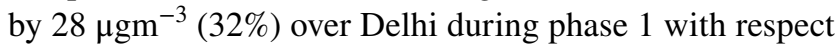
to the levels during 2019. However, the surface $\mathrm{O}_{3}$ levels were seen to be within the variabilities (standard deviation) during subsequent phases. $\mathrm{O}_{3}$ levels over Kolkata showed an enhancement by $49.2{\mu \mathrm{gm}^{-3}}$ (83\%) during phase 1 with respect to the levels during 2019. This highlights the nonlinear ozone chemistry over these regions. Large reduction in $\mathrm{NO}_{2}$ (discussed subsequently), a major $\mathrm{O}_{3}$ precursor, could have caused $\mathrm{O}_{3}$ reduction over Delhi in phase 1. However, enhancement or reduction depends upon changes in $\mathrm{NO}_{2}$ with respect to $\mathrm{NO}$ as well as Volatile Organic Compounds (VOCs). The $\mathrm{NO}_{2}$ reduction was relatively less over Kolkata and the changes in NO as well as VOCs would have contributed to $\mathrm{O}_{3}$ enhancement during phase $1 . \mathrm{O}_{3}$ levels remained comparable during phases 2-5 concerning the values during 2019 over Delhi as well as Kolkata. The daily mean $\mathrm{O}_{3}$ over Delhi and Kolkata were consistently below $80 \mathrm{\mu gm}^{-3}$ during 2019 as well as 2020 . Figure 3c shows the frequency distribution of 8-h maximum $\mathrm{O}_{3}$ during entire lockdown period with many occasions of $\mathrm{O}_{3}$ exceeding the NAAQS limits. While the broad $\mathrm{O}_{3}$ distribution shifted to lower values over Delhi, it has squeezed with greater frequencies over $40-60{\mu \mathrm{gm}^{-3}}$ over Kolkata.

The frequency distribution of 1-h maximum $\mathrm{O}_{3}$ (Fig. 4) shows skewed distribution. The maximum 1-h $\mathrm{O}_{3}$ values were reported for 13:00-14:00 for the year 2019 which got shifted by $2 \mathrm{~h}$ during the pandemic. Time of maximum $\mathrm{O}_{3}$ depends upon the availability of precursor gases, solar radiation, ambient temperature and evolution of boundary layer. With reduction in precursor concentrations, influences of temperature $\left(38.7{ }^{\circ} \mathrm{C} ; 32-48{ }^{\circ} \mathrm{C}\right)$ maximum in the afternoon hours (14-16 h) could have contributed to $\mathrm{O}_{3}$ maximum around $15 \mathrm{~h}$ during the lockdown. The shift in peak $\mathrm{O}_{3}$ time is about $2 \mathrm{~h}$ over Delhi. However, such effect was less pronounced over Kolkata which experienced daily maximum $\mathrm{O}_{3}$ most frequently at $14 \mathrm{~h}$ as compared to $13 \mathrm{~h}$ seen during 2019. Interestingly, there are higher number of occurrences of daily maximum at night-time over Kolkata. The 8-h maximum $\mathrm{O}_{3}$ frequency distribution is shown in Figure S4.

$\mathrm{NO}_{2}$ levels over Delhi and Kolkata were below daily NAAQS limits $\left(80 \mathrm{\mu gm}^{-3}\right)$ during lockdown period as well as the same period of 2019 (Figure S5). Large reductions by $35-58 \%\left(14.6-29.9{\mu \mathrm{gm}^{-3}}^{-3}\right.$ were observed over Delhi (Fig. 5a) with a shift in the peak of frequency distribution to $15-20 \mu \mathrm{gm}^{-3}$ bin from $40-45 \mu \mathrm{gm}^{-3}$ in 2019 (Fig. 5 b). The $\mathrm{NO}_{2}$ reductions over Delhi during phases 1-3 are seen to be beyond 2-sigma (standard deviation), which are not observed for other pollutants in both the locations. The reduction was about $50 \%$ over Kolkata during phases 1-2, whereas during the subsequent phases $\mathrm{NO}_{2}$ levels were within the variabilities. Also, there was a slight shift in frequency distribution, and the peak frequency was observed over the $10-15 \mu \mathrm{gm}^{-3}$ bin.

Night-time $\mathrm{O}_{3}$ (averaged over 2100-0500 h local time) shows a prominent enhancement (by 11 ppbv or $124 \%$ ) over Delhi (Fig. 6a) coinciding with the reduction in NO by 32 ppbv (90\%; Fig. 6b). This shows that the night-time $\mathrm{O}_{3}$ titration by NO has been weakened, whereas, the noontime $\mathrm{O}_{3}$ buildup has sustained resulting into higher night-time $\mathrm{O}_{3}$. Typically, night-time $\mathrm{O}_{3}$ levels are low in such urban environments ( 9 ppbv; Fig. 6a). These changes suggest profound impacts of emission reductions on the urban air chemistry, which are also anticipated to affect particle-phase processes. Similar $\mathrm{O}_{3}$ enhancement is reported over cities in Europe (17\%) and Wuhan, China (36\%) recently (Sicard et al. 2020). 


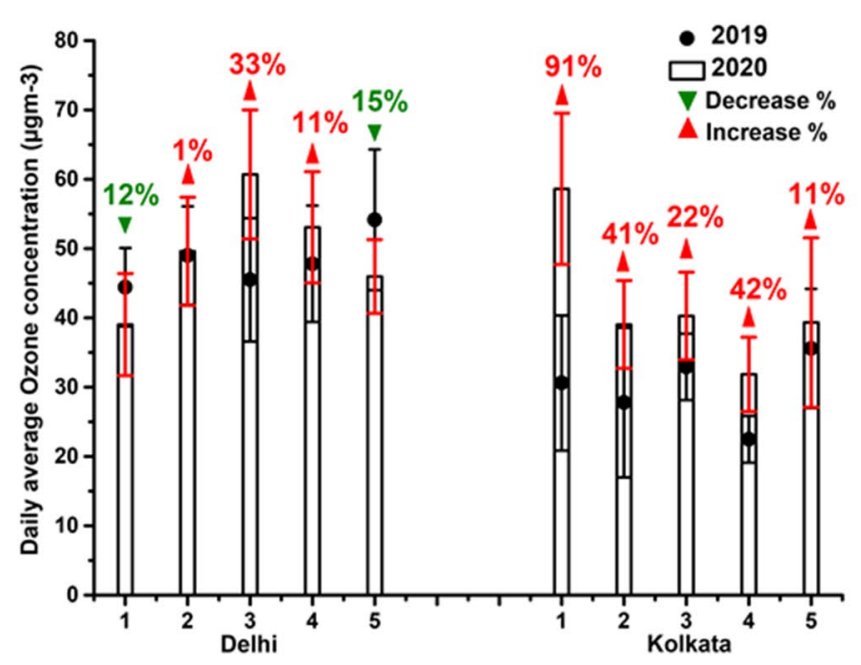

(Lockdown phases)

Delhi (a)

(Lockdown phases)

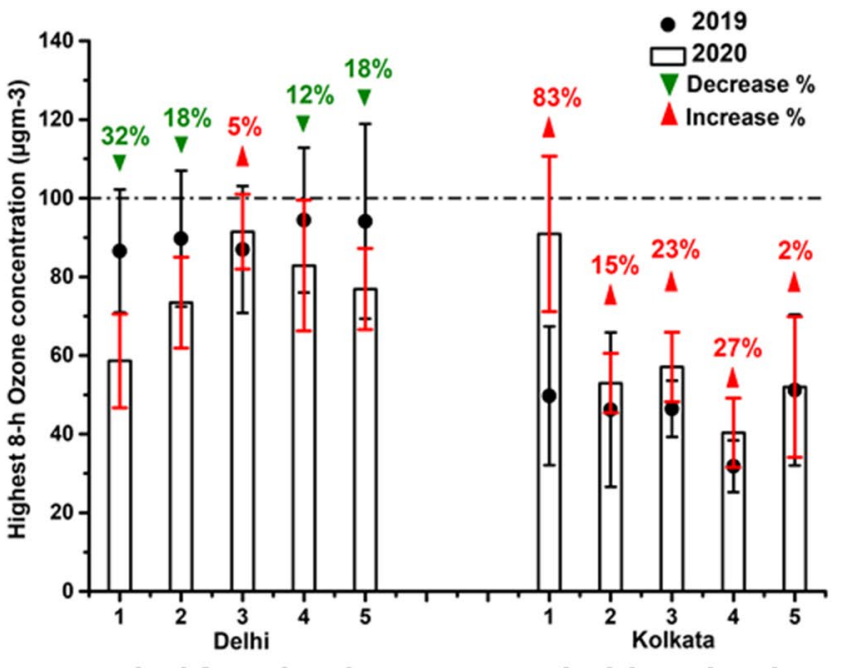

(Lockdown phases)

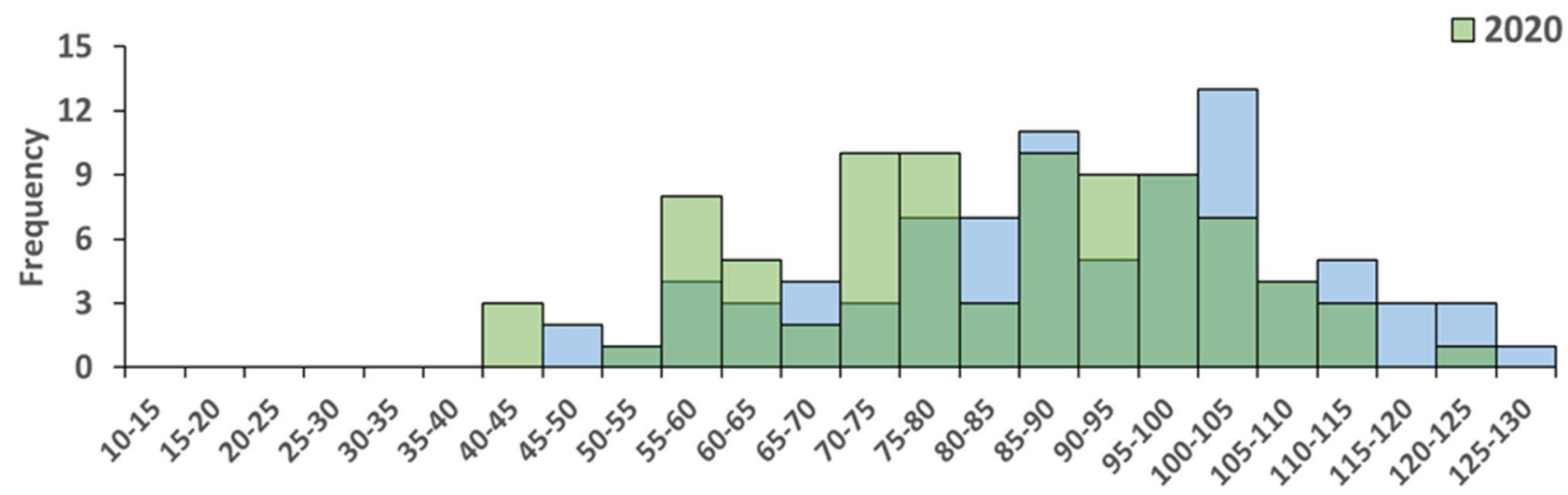

Kolkata

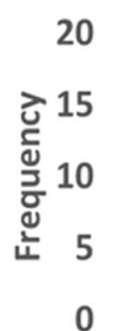

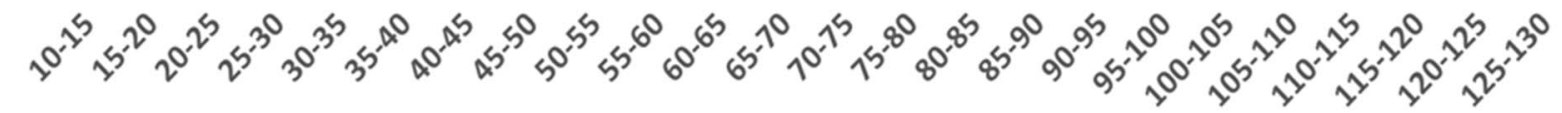

03 Concentration Range $\left(\mu \mathrm{gm}^{-3}\right)$

(c)

Fig. 3 Change in (a) daily $\mathrm{O}_{3}$; (b) maximum 8-h $\mathrm{O}_{3}$; (c) frequency distribution of daily $\mathrm{O}_{3}$ during lockdown phases of 2020 and the same period of 2019 
Fig. 4 Frequency distribution of 1-h maximum $\mathrm{O}_{3}$ concentration during lockdown phases of 2020 and the same period of 2019

Delhi

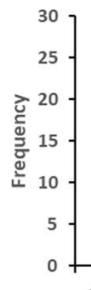

$\square 2020$

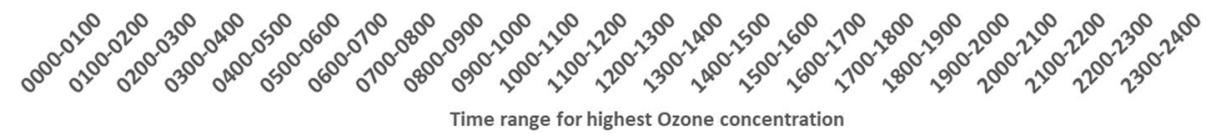

Kolkata

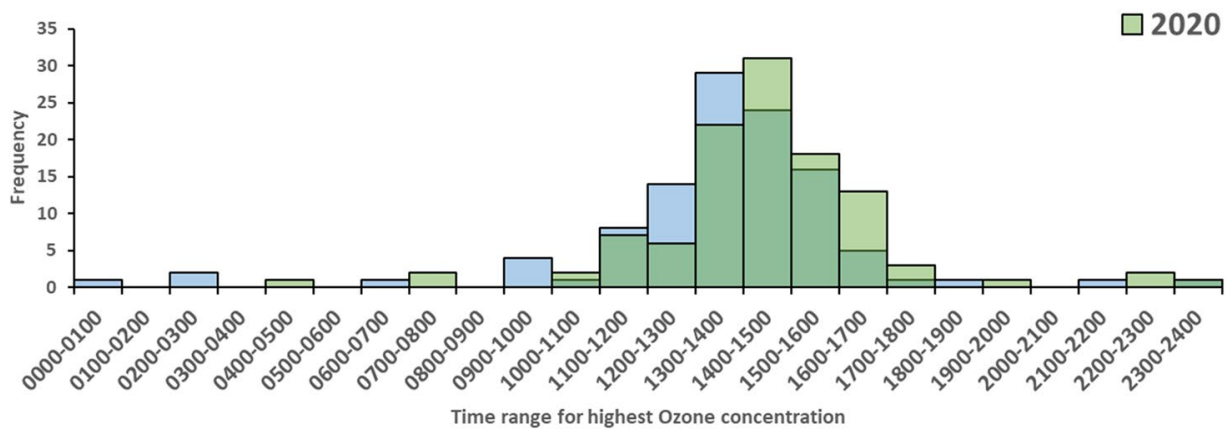

Time range for highest Ozone concentration

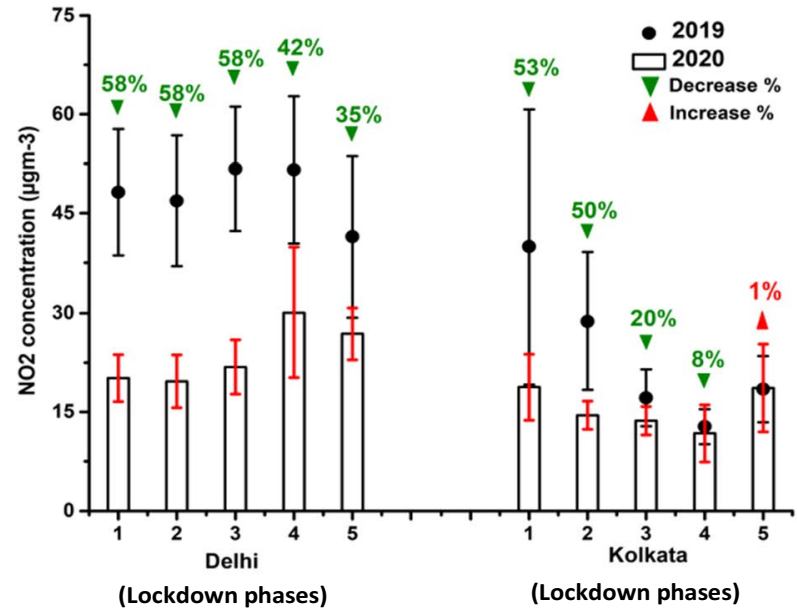

(a)
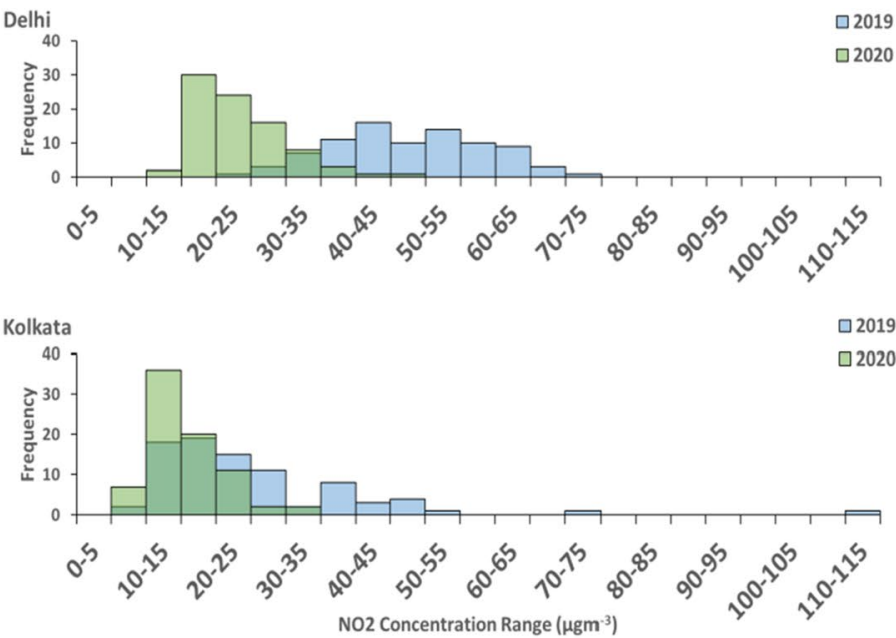

(b)

Fig. 5 (a) Change in daily $\mathrm{NO}_{2}$ concentrations; (b) frequency distribution of $\mathrm{NO}_{2}$ concentrations during lockdown phases of 2020 and the same period of 2019

\section{$\mathrm{SO}_{2}$ and $\mathrm{NH}_{3}$}

Similar to $\mathrm{NO}_{2}, \mathrm{SO}_{2}$ remained within the daily NAAQS limit during lockdown and the same period of 2019 (Figure S6). The $\mathrm{SO}_{2}$ levels were $14.4-21.5{\mu \mathrm{gm}^{-3}}^{-3}$ during 2019 over Delhi which reduced to $13.6-17 \mu \mathrm{gm}^{-3}$. The $\mathrm{SO}_{2}$ levels in Kolkata were enhanced to $13.6-17{\mu g^{-3}}^{-3}$ during the lockdown from 5.1-12.5 $\mu \mathrm{gm}^{-3}$ during 2019. The increase in $\mathrm{SO}_{2}$ levels observed in the Kolkata region is not clear, but speculation could be a slower reduction in the local activities towards the lockdown (Chakraborty et al. 2021). $\mathrm{SO}_{2}$

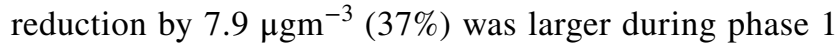
over Delhi (Fig. 7a), and reductions were lower (6-30\%) during other phases and within typical variabilities. Peak 

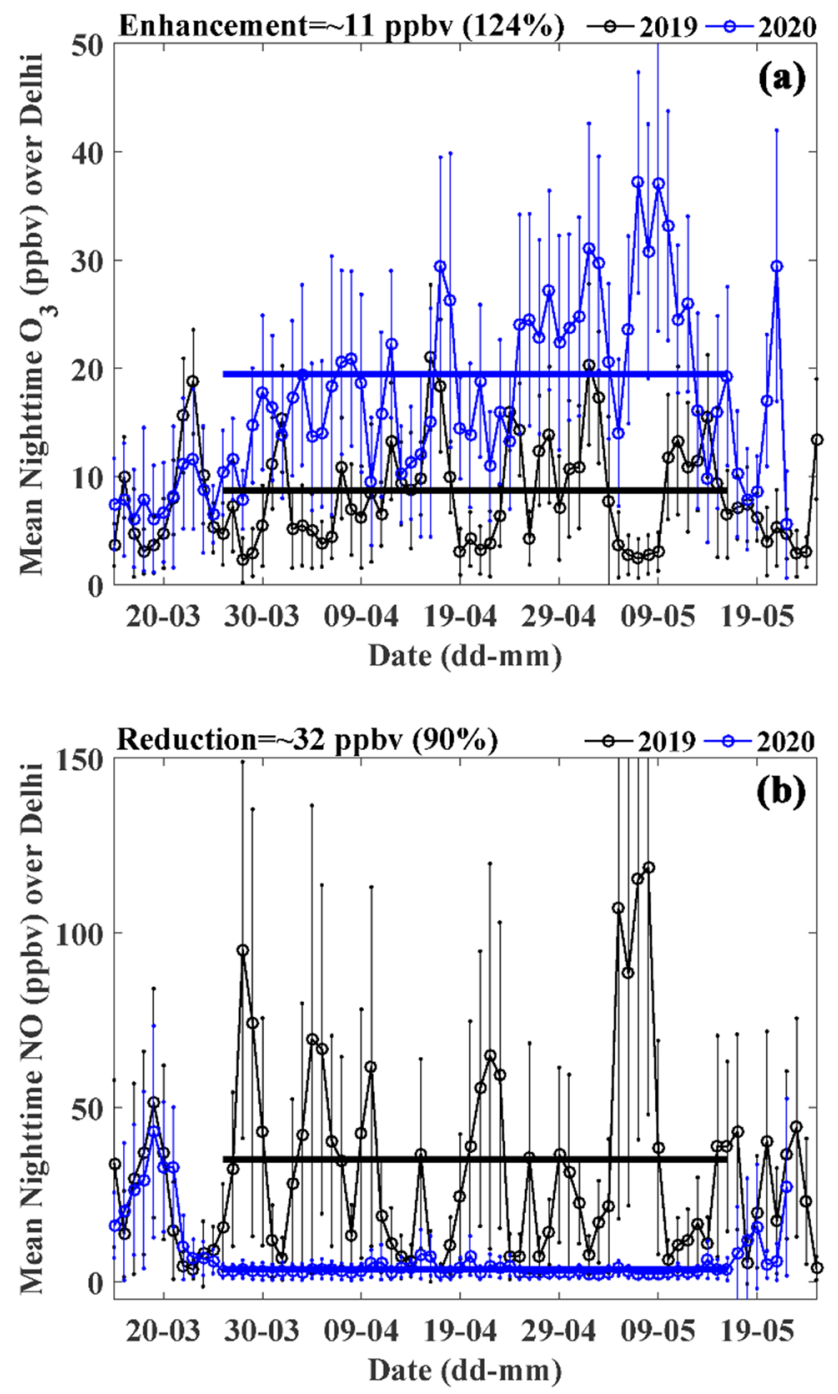

Fig. 6 Night-time surface $\mathrm{O}_{3}$ and $\mathrm{NO}$ variations over Delhi during March-May 2019 (black) and 2020 (blue) covering the lockdown period. Error bars represent standard deviations corresponding to spatial variability over Delhi. Horizontal lines represent the mean

of the frequency distribution shifted to $12-15 \mu \mathrm{gm}^{-3}$ during the lockdown from $20-22.5{\mu \mathrm{gm}^{-3}}^{-3}$ the preceding year (Fig. 7b). As expected, the frequency distribution was shifted to lower range and became skewed for Delhi. $\mathrm{SO}_{2}$ levels remained well within variability (1-sigma standard deviation) over Kolkata during the lockdown phases except during phases 1 and 3 .

The mean concentrations of $\mathrm{CO}$ were $0.9 \mathrm{mg} \mathrm{m}^{-3}$ $\left(0.7-1.0 \mathrm{mg} \mathrm{m}^{-3}\right)$ and $0.5 \mathrm{mg} \mathrm{m}^{-3}\left(0.4-0.7 \mathrm{mg} \mathrm{m}^{-3}\right)$ over Delhi and Kolkata, respectively, during lockdown phases (Figure S7). The reduction was estimated to be in the range of 0.3-0.6 $\mathrm{mg} \mathrm{m}^{-3}$ (23-49\%) during lockdown phases over Delhi (Fig. 8a), with shift in peak of distribution to lower range $\left(0.8-1 \mathrm{mg} \mathrm{m}^{-3}\right)$ (Fig. 8b). The reduction was beyond 1-sigma standard deviation during phases 1-3 over Delhi. Similar to the case of $\mathrm{SO}_{2}, \mathrm{CO}$ concentrations showed insignificant changes over Kolkata within the variabilities.

$\mathrm{NH}_{3}$ also showed a significant reduction by $25 \%$ over Delhi during phase 1 , whereas it remained within the variabilities during other phases (Fig. 9a). This is reflected in a marginal shift towards a lower range of values in the frequency distribution (Fig. 9b). In contrast to Delhi, $\mathrm{NH}_{3}$ showed some enhancement during phases $3-5$ over Kolkata (by $12.3-18.7 \mu \mathrm{gm}^{-3}$ ). The increase in $\mathrm{NH}_{3}$ levels could be due to various factors such as increase in emission from dumping grounds and cattle rearing in the surrounding region (Gupta et al. 2008). Cyclone 'Amphan' in Kolkata during the lockdown period brought marine airmass that could have higher background levels due to the chemistry of nitrogen-containing compounds and excretion of zooplanktons near the sea surface (Quinn et al. 1996). Increase in vitalisation (ammonium to ammonia) under moist conditions due to cyclone-related rain could also have also a contribution. The peak of frequency distribution shifted towards $20-25 \mu \mathrm{gm}^{-3}$ during lockdown period from 5-10 $\mu \mathrm{gm}^{-3}$ in Kolkata (Fig. 9b). Nevertheless, the $\mathrm{NH}_{3}$ levels over these megacities remained below the NAAQS limits during 2020 as well as 2019 (Figure S8).

\section{Comparison with NAAQS standard and implications}

Delhi witnessed $98 \%$ of its days ( $25^{\text {th }}$ March $-17^{\text {th }}$ June) with $\mathrm{PM}_{10}$ concentration exceeding the safe limits in 2019, which dropped significantly to $61 \%$ in 2020 during the lockdown (Fig. 10). Kolkata had observed $25 \%$ of the days exceeding the NAAQS limits for $\mathrm{PM}_{10}$ in 2019, but no days were observed with concentrations in exceedance of NAAQS during lockdown. The number of days with $\mathrm{PM}_{2.5}$ levels higher than the prescribed safe limits fell from $77 \%$ in 2019 to $21 \%$ in 2020 over Delhi, whereas Kolkata did not experience exceedances during 2020 as compared to $13 \%$ in the preceding year. Concentration of $\mathrm{NO}_{2}$ and $\mathrm{SO}_{2}$ levels during the years 2019 and 2020 was seen to be within the safe limits. The ambient $\mathrm{NH}_{3}$ levels also did not exceed the safe limits during both the years in both the megacities. Delhi witnessed $32 \%$ of its days which recorded higher 8-h CO levels in ambient air during 2019, but such instances were not observed during the lockdown. The 8-h ozone levels higher than the NAAQS safe limits were recorded in $34 \%$ of total days of study period during the year 2019 which dropped to $18 \%$ due to lockdown. Meanwhile Kolkata experienced rise in by $8 \%$ in number of days exceeding safe limits of surface ozone as compared to 2019.

\section{Summary and conclusions}

To limit the spread of COVID-19 infections, the Government of India imposed lockdown during 25 March-31 May 2020 in a phased manner, which caused cessation in 


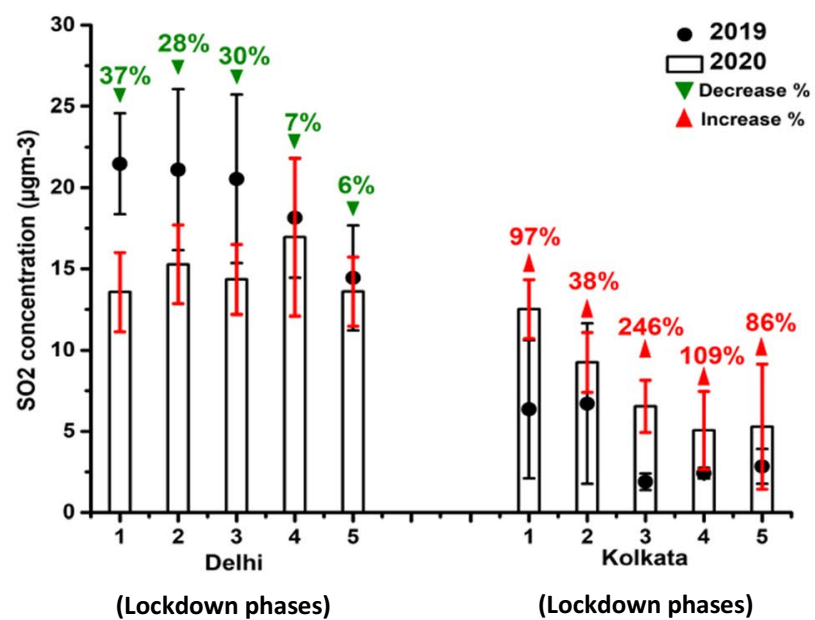

(a)

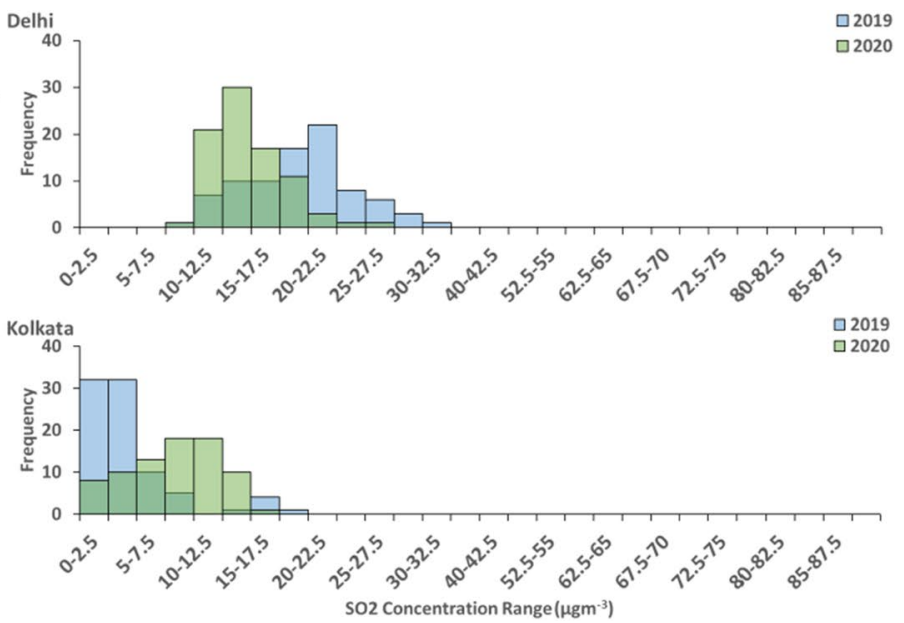

(b)

Fig. 7 (a) Change in daily $\mathrm{SO}_{2}$ concentrations; (b) frequency distribution of $\mathrm{SO}_{2}$ concentrations during lockdown phases of 2020 and the same period of 2019

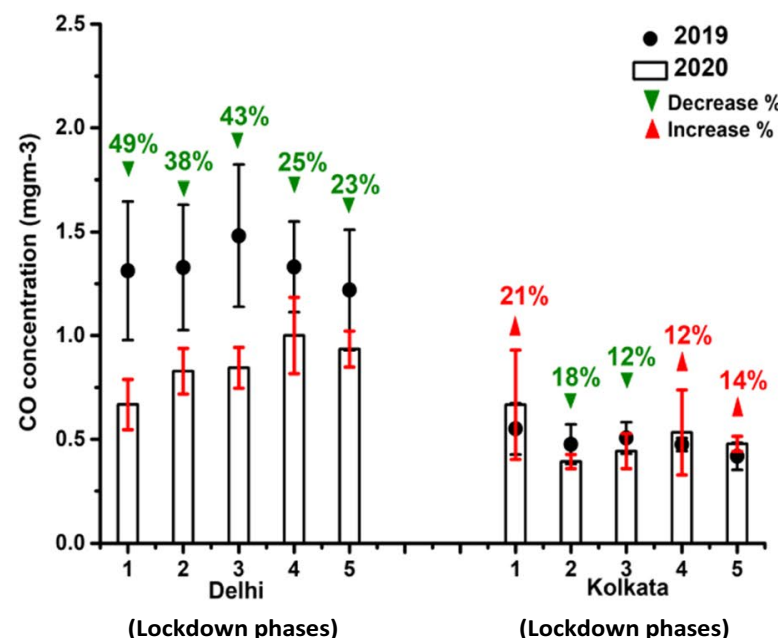

(a)
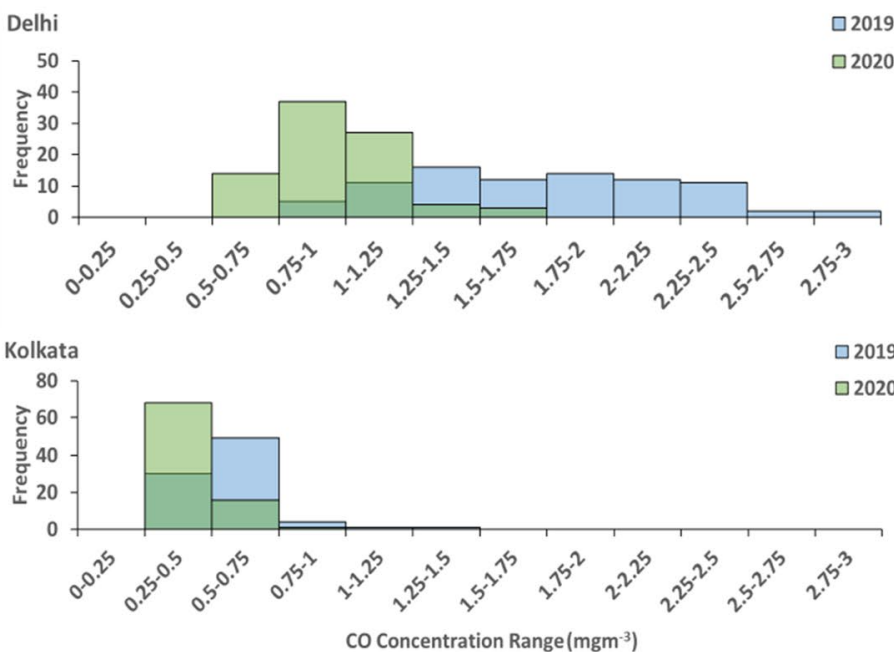

(b)

Fig. 8 (a) Change in daily $\mathrm{SO}_{2}$ concentrations; (b) frequency distribution of $\mathrm{SO}_{2}$ concentrations during lockdown phases of 2020 and the same period of 2019

anthropogenic activities. The strict actions taken to curtail the traffic movement and activities in the industrials sectors drastically reduced the pollution levels resulting in air quality levels under the safe limits over Delhi and Kolkata. Many studies have reported decline in pollution levels in Indian cities as a result of the lockdown (Bera et al. 2021; Jain and Sharma 2020; Kumari et al. 2020). The air quality during the lockdown in the Indian megacities exhibited significant reductions in $\mathrm{NO}_{2}$ (Gautam et al., 2020) and particulate matter concentrations while the daily mean $\mathrm{O}_{3}$ concentration showed some enhancements due to non-linear photochemistry, lower concentration of $\mathrm{O}_{3}$ titrating trace gases (e.g. nitric oxide) and more intense solar radiation (Bedi et al. 2020; Mor et al. 2021; Sharma et al. 2020; Singh et al. 2020). The key findings of the present study are as follows:

- $\mathrm{PM}_{2.5}$ levels were reduced by $17-66 \%$ over the Delhi and Kolkata. The number of NAAQS exceedance days for $\mathrm{PM}_{2.5}$ were 65 and 11 days over Delhi and Kolkata in 2019 which were reduced to 18 and zero days respectively due to the lockdown. 


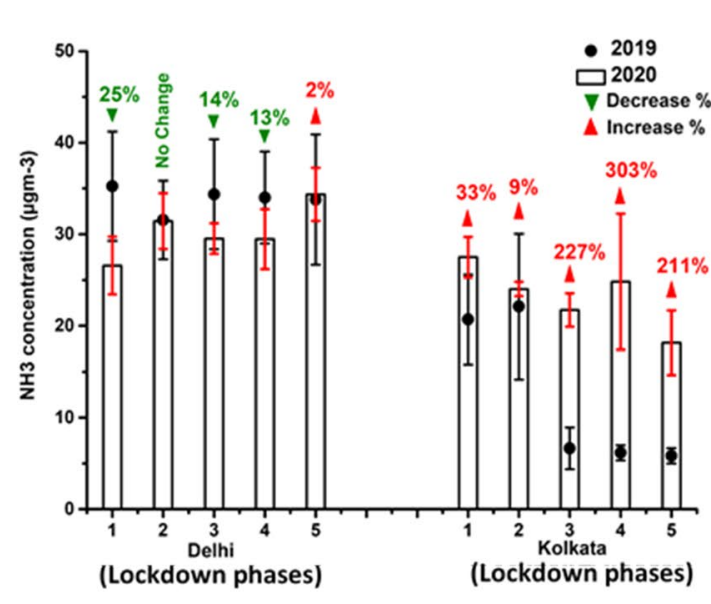

(a)

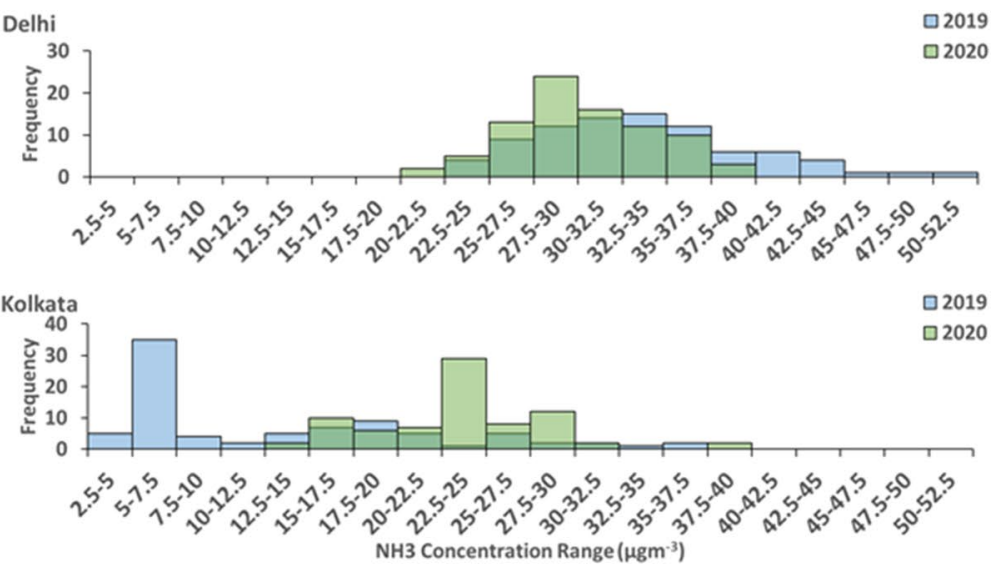

(b)

Fig. 9 (a) Change in $\mathrm{NH}_{3}$ concentrations; (b) frequency distribution of $\mathrm{NH}_{3}$ concentrations during lockdown phases of 2020 and the same period of 2019

- $\mathrm{PM}_{10}$ concentration levels reduced in the range of 18-69\% over Delhi and Kolkata combined. The number of days with $\mathrm{PM}_{10}$ above the NAAQS safe limits reduced from 83 to 52 days in Delhi and from 21 days to zero days in Kolkata due to the lockdown.

- 1-h maximum $\mathrm{O}_{3}$ peak in Delhi, which was seen at 13:00-14:00 h during 2019, was delayed by $\sim 2$ h during lockdown in 2020. Whereas, the $\mathrm{O}_{3}$ peak in Kolkata shifted by $1 \mathrm{~h}$ to 14:00-15:00. This shift in $\mathrm{O}_{3}$ peak is attributed to interplay between meteorology and reduced levels of $\mathrm{O}_{3}$ precursors.

- Besides the large reductions in mean concentrations, the peak of frequency distribution for all trace gases

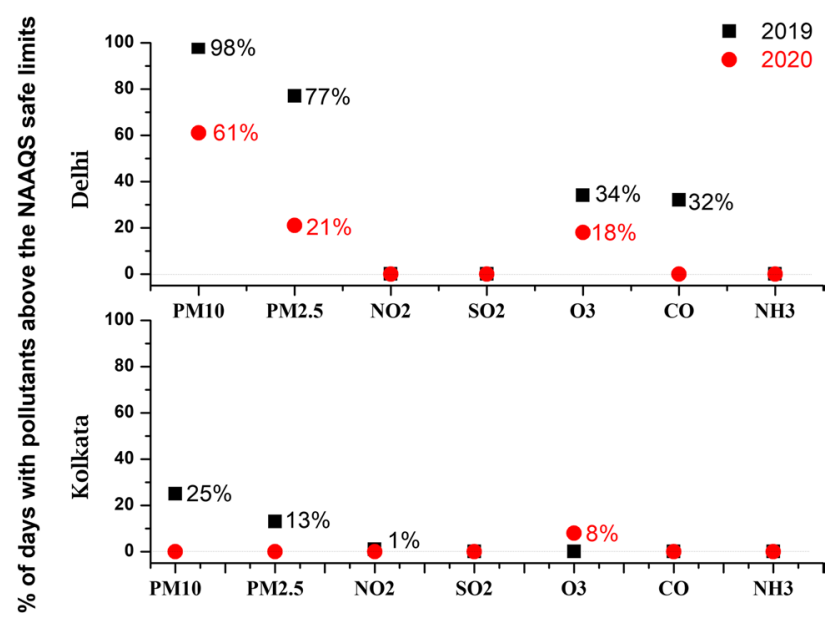

Fig. 10 Percentage of days with pollutant levels exceeding the NAAQS safe limits for the lockdown phases of 2020 and the same period of 2019. There are no exceedances in NAAQS levels except for $\mathrm{O}_{3}$ during lockdown period over Kolkata was shifted to lower range of concentrations $\left(\mathrm{NO}_{2}\right.$ : $10-15 \mu \mathrm{gm}^{-3}$; CO: $0.25-0.50 \mu \mathrm{gm}^{-3}$ ), except for $\mathrm{SO}_{2}$ and $\mathrm{NH}_{3}$ in Kolkata.

- In general, $\mathrm{O}_{3}$ showed higher levels as compared to 2019 over both Delhi and Kolkata. However, there was some decrease in maximum 8-h and daily mean $\mathrm{O}_{3}$ over Delhi during phases 1 and 5. A prominent night-time enhancement in ozone $(120 \% ; 11 \mathrm{ppbv})$ over Delhi was due to weaker chemical sink of $\mathrm{O}_{3}$ during phases 1-3.

The quantitative analyses on the changes in air quality with varying strength of emissions during COVID-19 lockdown provide valuable insights for designing mitigation strategies also in the normal conditions. Air quality variations and slight ozone enhancements in some phases of the lockdown unravel air chemistry in background conditions over this part of the world. The study based on actual conditions performed here would help evaluating modelling studies and emission inventories to explore the mitigation pathways.

Supplementary Information The online version contains supplementary material available at https://doi.org/10.1007/s11356-021-16874-z.

Acknowledgements Authors gratefully acknowledge the Central Pollution Control Board, Ministry of Environment, Forest and Climate Change (MoEFCC) for the ground-based observations of $\mathrm{PM}_{2.5}, \mathrm{PM}_{10}$, $\mathrm{NO}_{2}, \mathrm{SO}_{2}, \mathrm{O}_{3}, \mathrm{CO}$ and $\mathrm{NH}_{3}$ obtained from website, https://app.cpcbc cr.com/ccr,

Author contribution AM had conducted the data analyses and wrote the draft. SKS and TKM conceptualised the idea and contributed in shaping the manuscript. IG and NO contributed to the design and provided inputs on the analysis. 
Availability of data and materials All data generated or analysed during this study are included in this published article and its supplementary information files.

\section{Declarations}

Ethics approval and consent to participate Not applicable.

Consent for publication Not applicable.

Competing interests The authors declare no competing interests.

\section{References}

Ansari TU, Ojha N, Chandrasekar R, Balaji C, Singh N, Gunthe SS (2016) Competing impact of anthropogenic emissions and meteorology on the distribution of trace gases over Indian region. J Atmos Chem 73(4). https://doi.org/10.1007/s10874-016-9331-y

Bedi JS, Dhaka P, Vijay D, Aulakh RS, Gill JPS (2020) Assessment of Air quality changes in the Four metropolitan cities of India during COVID-19 pandemic lockdown. Aerosol and Air Quality Research 20(10):2062-2070. https://doi.org/10.4209/aaqr.2020. 05.0209

Bera B, Bhattacharjee S, Shit PK, Sengupta N, Saha S (2021) Significant impacts of COVID-19 lockdown on urban air pollution in Kolkata (India) and amelioration of environmental health. Environ Dev Sustain 23(5):6913-6940. https://doi.org/10.1007/ s10668-020-00898-5

Chakraborty M, Debnath S, Ghosh S (2021) A study during lockdown period based on AQI over Indian mega cities during COVID-19. J Phys: Conf Ser 1797(1):012056. https://doi.org/10.1088/17426596/1797/1/012056

Chowdhury S, Dey S, Guttikunda S, Pillarisetti A, Smith KR, Di Girolamo L (2019) Indian annual ambient air quality standard is achievable by completely mitigating emissions from household sources. Proc Natl Acad Sci 116(22):10711-10716. https://doi. org/10.1073/pnas.1900888116

Chutia L, Ojha N, Girach IA, Sahu LK, Alvarado LMA, Burrows JP, Pathak B, Bhuyan PK (2019) Distribution of volatile organic compounds over Indian subcontinent during winter: WRF-chem simulation versus observations. Environ Pollut 252:256-269. https:// doi.org/10.1016/j.envpol.2019.05.097

Dhaka SK, Chetna, Kumar V, Panwar V, Dimri AP, Singh N, Patra PK, Matsumi Y, Takigawa M, Nakayama T, Yamaji K, Kajino M, Misra P, Hayashida S (2020) PM2.5 diminution and haze events over Delhi during the COVID-19 lockdown period: an interplay between the baseline pollution and meteorology. Sci Rep 10(1):13442. https://doi.org/10.1038/s41598-020-70179-8

Firdaus G, Ahmad A (2011) Changing air quality in Delhi, India: determinants, trends, and policy implications. Reg Environ Change 11(4):743-752. https://doi.org/10.1007/s10113-011-0207-z

Ghude SD, Chate DM, Jena C, Beig G, Kumar R, Barth MC, Pfister GG, Fadnavis S, Pithani P (2016) Premature mortality in India due to PM2.5 and ozone exposure. Geophys Res Lett 43(9):4650 4658. https://doi.org/10.1002/2016GL068949

Girach IA, Ojha N, Babu SS (2021) Ozone chemistry and dynamics at a tropical coastal site impacted by the COVID-19 lockdown. J Earth Syst Sci 8.https://doi.org/10.1007/s12040-021-01666-3

Gupta AK, Karar K, Srivastava A (2007) Chemical mass balance source apportionment of PM10 and TSP in residential and industrial sites of an urban region of Kolkata India. Journal of Hazardous Materials 142(1-2):279-287. https://doi.org/10. 1016/j.jhazmat.2006.08.013

Gupta AK, Karar K, Ayoob S, John K (2008) Spatio-temporal characteristics of gaseous and particulate pollutants in an urban region of Kolkata India. Atmospheric Research 87(2):103-115. https://doi.org/10.1016/j.atmosres.2007.07.008

Gurjar BR, Ravindra K, Nagpure AS (2016) Air pollution trends over Indian megacities and their local-to-global implications. Atmos Environ 142:475-495. https://doi.org/10.1016/j.atmos env.2016.06.030

Jain S, Sharma T (2020) Social and travel lockdown impact considering coronavirus disease (COVID-19) on air quality in megacities of India: present benefits, future challenges and way forward. Aerosol and Air Quality Research 20:1222-1236. https:// doi.org/10.4209/aaqr.2020.04.0171

Kumar V, Sarkar C, Sinha V (2016) Influence of post-harvest crop residue fires on surface ozone mixing ratios in the N.W. IGP analyzed using 2 years of continuous in situ trace gas measurements. Journal of Geophysical Research: Atmospheres 121(7):3619-3633. https://doi.org/10.1002/2015JD024308

Kumar V, Chandra BP, Sinha V (2018) Large unexplained suite of chemically reactive compounds present in ambient air due to biomass fires. Sci Rep 8(1):626. https://doi.org/10.1038/ s41598-017-19139-3

Kumar R, Barth MC, Pfister GG, Nair VS, Ghude SD, Ojha N (2015) What controls the seasonal cycle of black carbon aerosols in India? J Geophys Res 120(15). https://doi.org/10.1002/2015J D023298

Kumari S, Lakhani A, Kumari KM (2020) COVID-19 and air pollution in Indian cities: world's most polluted cities. Aerosol and Air Quality Research 20(12):2592-2603. https://doi.org/ 10.4209/aaqr.2020.05.0262

Le T, Wang Y, Liu L, Yang J, Yung YL, Li G, Seinfeld JH (2020) Unexpected air pollution with marked emission reductions during the COVID-19 outbreak in China. Science 369(6504):702706. https://doi.org/10.1126/science.abb7431

Lelieveld J, Evans JS, Fnais M, Giannadaki D, Pozzer A (2015) The contribution of outdoor air pollution sources to premature mortality on a global scale. Nature 525(7569):367-371. https:// doi.org/10.1038/nature 15371

Lu H, Fang G (2002) Estimating the frequency distributions of PM10 and PM2.5 by the statistics of wind speed at Sha-Lu Taiwan. Sci Total Environ 298(1-3):119-130. https://doi.org/10.1016/ S0048-9697(02)00164-X

Miles GH, Jakeman AJ, Bai J (1991) A method for predicting the frequency distribution of air pollution from vehicle traffic, basic meteorology, and historical concentrations to assist urban planning. Environ Int 17(6):575-580. https://doi.org/10.1016/01604120(91)90169-Q

Molina MJ, Molina LT (2004) Megacities and atmospheric pollution. J Air Waste Manag Assoc 54(6):644-680. https://doi.org/10. 1080/10473289.2004.10470936

Mondal A, Lata S, Ghosh P, Mondal S, Devalla V, Mondal AK (2021) Upliftment of societal lockdown by Indian government amid CoVID-19 crisis: boon for some and bane for others [Preprint]. https://doi.org/10.31124/advance.14806377

Mor S, Kumar S, Singh T, Dogra S, Pandey V, Ravindra K (2021) Impact of COVID-19 lockdown on air quality in Chandigarh, India: understanding the emission sources during controlled anthropogenic activities. Chemosphere 263:127978. https:// doi.org/10.1016/j.chemosphere.2020.127978

Nigam R, Pandya K, Luis AJ, Sengupta R, Kotha M (2021) Positive effects of COVID-19 lockdown on air quality of industrial cities (Ankleshwar and Vapi) of Western India. Sci Rep 11(1):4285. https://doi.org/10.1038/s41598-021-83393-9 
Ojha N, Sharma A, Kumar M, Girach I, Ansari TU, Sharma SK, Singh N, Pozzer A, Gunthe SS (2020) On the widespread enhancement in fine particulate matter across the Indo-Gangetic Plain towards winter. Sci Rep 10(1):5862. https://doi.org/10.1038/ s41598-020-62710-8

Ojha N, Naja M, Singh KP, Sarangi T, Kumar R, Lal S, Lawrence MG, Butler TM, Chandola HC (2012) Variabilities in ozone at a semi-urban site in the Indo-Gangetic Plain region: association with the meteorology and regional processes. Journal of Geophysical Research Atmospheres 117(20). https://doi.org/10.1029/ 2012JD017716

Pathakoti M, Muppalla A, Hazra S, Dangeti M, Shekhar R, Jella S, Mullapudi SS, Andugulapati P, Vijayasundaram U (2020) An assessment of the impact of a nation-wide lockdown on air pollution-a remote sensing perspective over India. Atmospheric Chemistry and Physics Discussions 2020:1-16. https://doi.org/ 10.5194/acp-2020-621

Quinn PK, Barrett KJ, Dentener FJ, Lipschultz F, Six KD (1996) Estimation of the air/sea exchange of ammonia for the North Atlantic Basin. In R. W. Howarth (Ed.), Nitrogen cycling in the North Atlantic Ocean and its watersheds (pp. 275-304). Springer Netherlands. https://doi.org/10.1007/978-94-009-1776-7_9

Saltzman BE (1997) Health risk assessment of fluctuating concentrations using lognormal models. J Air Waste Manag Assoc 47(11):1152-1160. https://doi.org/10.1080/10473289.1997.10464 064

Sarangi T, Naja M, Ojha N, Kumar R, Lal S, Venkataramani S, Kumar A, Sagar R, Chandola HC (2014) First simultaneous measurements of ozone, $\mathrm{CO}$, and $\mathrm{NO}_{y}$ at a high-altitude regional representative site in the central Himalayas: ozone, $\mathrm{CO}$, and $\mathrm{NO}_{y}$ over the Himalayas. Journal of Geophysical Research: Atmospheres 119(3):1592-1611. https://doi.org/10.1002/2013JD020631

Sathe Y, Gupta P, Bawase M, Lamsal L, Patadia F, Thipse S (2021) Surface and satellite observations of air pollution in India during COVID-19 lockdown: implication to air quality. Sustain Cities Soc 66:102688. https://doi.org/10.1016/j.scs.2020.102688

Saxena A, Raj S (2021) Impact of lockdown during COVID-19 pandemic on the air quality of North Indian cities. Urban Climate 35:100754. https://doi.org/10.1016/j.uclim.2020.100754

Seinfeld JH, Pandis SN (1998) Atmospheric chemistry and physics: from air pollution to climate change. John Wiley \& Sons

Sen A, Abdelmaksoud AS, Nazeer Ahammed Y, Alghamdi MA, Banerjee T, Bhat MA, Chatterjee A, Choudhuri AK, Das T, Dhir A, Dhyani PP, Gadi R, Ghosh S, Kumar K, Khan AH, Khoder M, Maharaj Kumari K, Kuniyal JC, Kumar M, ..., Mandal TK (2017) Variations in particulate matter over Indo-Gangetic Plains and Indo-Himalayan Range during four field campaigns in winter monsoon and summer monsoon: role of pollution pathways.
Atmos Environ 154:200-224.https://doi.org/10.1016/j.atmosenv. 2016.12.054

Sharma A, Ojha N, Pozzer A, Mar KA, Beig G, Lelieveld J, Gunthe SS (2017) WRF-Chem simulated surface ozone over south Asia during the pre-monsoon: effects of emission inventories and chemical mechanisms. Atmos Chem Phys 17(23):14393-14413. https://doi. org/10.5194/acp-17-14393-2017

Sharma A, Ojha N, Pozzer A, Beig G, Gunthe SS (2019) Revisiting the crop yield loss in India attributable to ozone. Atmospheric Environment: X 1:100008. https://doi.org/10.1016/j.aeaoa.2019. 100008

Sharma S, Zhang M, Anshika G, J., Zhang, H., \& Kota, S. H. (2020) Effect of restricted emissions during COVID-19 on air quality in India. Sci Total Environ 728:138878. https://doi.org/10.1016/j. scitotenv.2020.138878

Sicard P, De Marco A, Agathokleous E, Feng Z, Xu X, Paoletti E, Rodriguez JJD, Calatayud V (2020) Amplified ozone pollution in cities during the COVID-19 lockdown. Sci Total Environ 735:139542. https://doi.org/10.1016/j.scitotenv.2020.139542

Singh RP, Chauhan A (2020) Impact of lockdown on air quality in India during COVID-19 pandemic. Air Qual Atmos Health 13(8):921-928. https://doi.org/10.1007/s11869-020-00863-1

Singh V, Singh S, Biswal A, Kesarkar AP, Mor S, Ravindra K (2020) Diurnal and temporal changes in air pollution during COVID-19 strict lockdown over different regions of India. Environ Pollut 266:115368. https://doi.org/10.1016/j.envpol.2020.115368

Singh V, Singh S, Biswal A (2021) Exceedances and trends of particulate matter (PM2.5) in five Indian megacities. Sci Total Environ 750:141461. https://doi.org/10.1016/j.scitotenv.2020.141461

Soni M, Ojha N, Girach IA (2021) Impact of COVID-19 lockdown on surface ozone build-up at an urban site in western India based on photochemical box modelling. Curr Sci 120(2):376-381. https:// doi.org/10.18520/cs/v120/i2/376-381

Srivastava S, Kumar A, Bauddh K, Gautam AS, Kumar S (2020) 21-day lockdown in India dramatically reduced air pollution indices in Lucknow and New Delhi, India. Bull Environ Contam Toxicol 105(1):9-17. https://doi.org/10.1007/s00128-020-02895-w

Srivastava AK, Bhoyar PD, Kanawade VP, Devara PCS, Thomas A, Soni VK (2021) Improved air quality during COVID-19 at an urban megacity over the Indo-Gangetic Basin: from stringent to relaxed lockdown phases. Urban Climate 36:100791. https://doi. org/10.1016/j.uclim.2021.100791

Publisher's note Springer Nature remains neutral with regard to jurisdictional claims in published maps and institutional affiliations. 